\title{
Editorial
}

\section{CANADA'S NEED FOR A NATIONAL STRATEGY FOR POSTSECONDARY EDUCATION}

HONOURABLE BILL ROMPKEY, P.C., M.P.

Grand Falls - White Bay - Labrador

"Where there is no vision, the people perish"

Proverbs 29: 18

"Postsecondary institutions - not just universities, but also colleges, research institutes, libraries, archives and the like - are part of the intellectual and cultural fabric of any society. The enduring strength of a society ultimately rests more on these institutions than on economic, industrial or military power."

Excerpt from: Parliamentary Task Force on Federal Provincial Fiscal Arrangements, 1981, p.121

An educated society is richer in every way. We have a rich society in Canada; but its quality, and certainly its economic health, is threatened by the crisis in postsecondary education.

The health of the Canadian society, and especially that of the Canadian economy, is tied in no small way to the health of postsecondary education. Both the private and public sectors need men and women liberally educated and at the leading edge of their discipline. Moreover industry and government are in need of the research done by the universities and other postsecondary institutions. In an age when one of the few constants is change, those companies, those sectors, those nations which grow and prosper are the ones who emphasize research and development and who have prospective employees educated and prepared to meet rapid change in the marketplace.

And yet in Canada there is a crisis in postsecondary education. To quote A. Johnson:

"The finances of Canada's universities and colleges are in a weakened and uncertain state."

At the same time the federal and provincial governments differ on how postsecondary education should be funded. There is a profound malaise concerning the priorities within higher education. Too little attention, for example, has been paid to the financing of research as opposed to core operations. These problems only add to the older but still unresolved crises of too many students and too few faculty, the difficulty of student mobility, meeting manpower objectives, and the enhancement of citizenship, language and cultural identity. The fact is that in this century with its satellites, lasers, computers, ICBM's, and 
transistor radios; in this century when the world is moving so rapidly to "the information economy", Canada, a leader in so many ways, has no national strategy for education.

In its comprehensive Review of Educational Policy of Canada published in 1976, the Organization for Economic Cooperation and Development (OECD) came to the following conclusions about the state of Canadian educational policy-making:

The lack of educational policies for the future is striking.

There is a need to define goals for education that fit a vision of national interest.

There is an array of exceptionally active programs derived from no explicitly stated overall national conception of the country's interest.

Decisions now have to be taken concerning the destination of the Canadian school system within an ordered view of the Canadian nation.

The fact that there is no federal department of education has created a kind of vacuum.

Politicians, parties and governments will not be able to avoid much longer taking some political stands, and that means also nationwide, and not simply province-oriented positions. They need to give Canadian answers to Canadian problems. Without political leadership and responsibility - and after all neither of these is forbidden under the BNA Act - a severe backlash against future educational development in Canada may be unavoidable.

In view of these statements, it is most disappointing that the Nielsen Task Force Report, or any other government response, has not dealt more seriously or definitively with education and research. As the Association of Universities and Colleges of Canada (AUCC) has said, the Nielsen Task Force "erred by not making a case for the continuation of federal support for postsecondary education." Rather than making a specific recommendation on federal financial support for postsecondary institutions, the study team lists a number of policy options. Speaking on behalf of the AUCC, Dr. D.L. Johnston criticized the study team for "skirting the issue of national priorities" by not setting down specific recommendations that reaffirm the federal role in support for postsecondary education.

As a smaller world forces us into greater interdependency, we are about to start a major national debate on free trade. We have repeatedly tried to come to grips with an industrial strategy. We have come through a recession that shook us and toughened us. We know the competition in the world will be greater than ever before. We know we have to reorganize, refinance, retool, reassess. And yet, while education and the education system is so fundamental, so essential, to all this, there is no national debate, no national emphasis, no national forum, no national strategy on education in Canada.

No other federal state in the world is in such a position and no self-respecting modern state should be. We purport to have a national financial strategy; a national trade strategy; a defence strategy; a transportation strategy; an immigration strategy; but no national education strategy. Of course each province has a 
provincial education strategy; but surely the whole is more than just the sum of its parts. The increasing presence of the Government of Canada in higher education cannot be ignored.

Higher education is financed to the extent of more than $50 \%$ from fiscal resources that have been provided by the Parliament of Canada. Yet the idea persists that postsecondary education is a purely provincial matter. On the contrary there is a massive and pervasive federal presence in higher education: in basic funding, in research funding, in professional and training programs, in a multitude of scholarship, bursary and student assistance programs, in northern studies, native studies, ocean studies, Canadian studies, multiculturalism, bilingualism, in international relations, in military studies and other fields, let alone in a sense of compelling national interest and responsibility.

There are legitimate and unavoidable federal interests in higher education relating to the role of the national government in ensuring that the country has adequate supplies of highly qualified people, that there is some equality of opportunity for young Canadians regardless of where they live, and that there is a development of the knowledge base that is required for economic growth and for national sovereignty.

It is especially important to examine the relationship between education and the arts in Canada and to emphasize the responsibility and role of the Government of Canada. A recent article by Mavor Moore in the Globe and Mail brought this into focus.

Moore raises key and pertinent questions about our national schools of art such as the National Theatre School in Montreal, the National Ballet School in Toronto, the Royal Winnipeg Ballet School, the Banff Centre School of Fine Arts and the Vancouver Playhouse School. He castigates us for our apathy towards the funding of artistic institutions in Canada. For example, he points out that the National Theatre School while turning out the most valuable young actors and theatre technicians in the country has annually had to scramble to avoid bankruptcy. Moore says the NTS is a reminder to Canadians that they possess something that transcends regional achievement.

"We seem willing to acknowledge that such things may happen, but unwilling to provide for them in our political structure. Even the fact that the NTS is known abroad as one of the world's leading theatre schools seems insufficient to persuade Canadians that it is worthy of official status and long-term support.

Apparently we feel the same about many of our so-called national institutions. We want not only to have our cake and eat it, in the sense of having the benefits of a nation with all the advantages of regionalism. We want to have our cake and eat it without having baked it in the first place."

Surely there is a need now as never before, now on the threshold of a smaller interdependent world with tougher competition among businesses, now when values and beliefs are constantly challenged, now at the beginning of the new information society, there is a need for greater co-ordination of Canadian education. 
The Social Science Federation of Canada stressed this in 1982 in its reaction to the conclusions of the Parliamentary Task Force on Fiscal Arrangements which recommended that the Council of Ministers of Education should serve as a forum for federal-provincial consultation. The Federation believed that such an approach would be ineffective, and instead recommended the creation of a Council to be called the Canadian Council on Research and Universities.

"... The principal mandate of the Council would be to discuss and articulate the objectives of legitimate concern to both federal and provincial governments in the area of higher education and research and to advise on the future orientation and content of federal policies in this area as well as the relationship of these policies to those of the provincial governments. In addition, the Council would assist the federal government in articulating more clearly and effectively its interest in higher education and research. At the moment these interests span various ministries and policy fields (spending envelopes) and appear poorly articulated and coordinated."

In 1984 the third volume of the Report of the Commission on Canadian Studies of the AUCC made similar recommendations. It presented an extensive analysis of the "crazy quilt" pattern of postsecondary education policy. It stressed the need for a national strategy for higher education and research with the universities and colleges and the federal and provincial governments playing appropriate roles in a co-operative fashion.

The authors of the Report proposed a consultative Committee on Postsecondary Education.

"In making this proposal the Commission is aware, of course, of the existence
of a variety of interprovincial, federal-provincial, and academic organizations
that work to this end, including for example, the Council of Ministers of
Education of Canada and bits and pieces of federal-provincial consultative
apparatus, as well as national voluntary associations such as the Association
of Universities and Colleges of Canada and the Association of Canadian
Community Colleges. The plain truth, however, is that these bodies have not
yet developed procedures and mechanisms remotely adequate to meet the
needs of the country for serious and continuing consultation and cooperation
in the field of higher education."

Thomas Symons also called for such a body in his paper "Ontario Universities in a Broader Context", presented to the Conference on Ontario Universities: Access, Operations and Funding, organized by the Ontario Economic Council. He cited the need for national strategies in higher education "that could result from consultation and cooperation of a more substantial and sustained order than now prevails among the universities, within the academic community, amongst the provinces, and between the provinces, the universities and the federal government."

Among his recommendations is the establishment of a Consultative Committee or Council on Postsecondary Education and Research to provide a continuing forum for representatives of the federal and provincial governments and of the postsecondary institutions. It would meet at regular intervals to explore plans and programs that can meet the growing needs of Canadians in the fields of higher education and research. 
It seems to me that to reach the goal of improved postsecondary education the first thing we need is a vehicle. And why not? After all we have national advisory councils on health, social welfare, economics, the status of women, mining, small business and others. Is education less important to the nation than these? $\mathrm{A}$ national advisory council on education would carry negligible cost; but the return in educational excellence could be tremendous.

Other federal states have found such a body useful and necessary. In both Germany and Switzerland, for example, there are, in addition to decision-making and administrative institutions at both the national and state levels, common institutions with representation from both levels of government. In Germany the two key planning and advisory bodies, the Bund-Landers Commission for Education Planning and Research Promotion and the Science Council, both have equal voting representation from the Bund and the Landers.

At the present time, I have a Private Member's Bill before the House of Commons. This legislation, Bill C-244, proposes the establishment of a Canadian Postsecondary Education Council. I have proposed a council, the majority of which would be nominated by the Provinces while a minority would be nominated by the Government of Canada, but would be drawn from the postsecondary education community. The final makeup of the Council is, of course, open to discussion and debate. Obviously a balance would have to be struck between the legal jurisdiction of the provinces and the pervasive and growing involvement of the national government. It would be funded jointly by the federal and provincial governments and its mandate would be to "provide a forum for the discussion of the development of postsecondary education in Canada and of interprovincial, national and international educational questions." One of its tasks would be to propose a national education strategy within three years.

The Canadian Teachers' Federation would go beyond this. It has advocated, in its submission to the Macdonald Royal Commission, the establishment of a Canadian Office of Education jointly supported by the Government of Canada and the governments of the provinces and territories. It would disseminate information nation-wide as well as promote research in education. It would study fiscal problems and recommend how they can be solved. It would co-ordinate federal education activities and promote common policies on education across Canada.

That Office would be supported by a Canadian Council of Education which would draw upon the advisory resources of a broad range of interests in Canadian society.

I support these proposals of the C.T.F. and believe they are objectives we should aspire to and attain. But as goals they would be more difficult to realize in the short term than the greater co-ordination of postsecondary education. If every journey begins with the first step, I believe a Canadian Postsecondary Education Council is a realistic beginning. It is something we can achieve. It is something we must achieve.

I believe that a national education strategy should be a top priority in Canada today. But we should first give some semblance of order to the hodge-podge that 
exists in Canadian education, so that we may better come to grips with that strategy. Better co-ordination of postsecondary education, and in time, the whole field of education is long overdue.

We are resource rich in Canada. But the greatest resource of all is our people and especially our young people. And yet the recent Senate Report on Youth tells us they are in danger of being "a lost generation". Does the 20th century belong to Canada as Sir Wilfrid Laurier said? Are we one of the top five countries in the world with growing influence? Are we coming of age internationally, discovering what we are, throwing off our sense of inferiority, competing head-to-head with the world leaders? Let's ask how our economy compares with West Germany's. And then ask how our education system compares. Let's ask how our economy compares to that of Japan. And then ask how our education system compares. What are our goals; what is our vision of Canada?

It is time to make education our number one priority. Let us aim at a national strategy for education and let us start by getting our act together. This is the greatest challenge facing Canada today and to fail to deal with it will be to put the nation at risk.

\section{LE CANADA A BESOIN D'UNE STRATÉGIE NATIONALE EN MATIÈRE D'ENSEIGNEMENT POSTSECONDAIRE}

\section{HONORABLE BILL ROMPKEY, P.C., DÉPUTÉ}

Grand Falls - White Bay - Labrador

"Quand il n'y a pas de révélation, le peuple est sans frein."

Proverbes 29: 18

Les institutions postsecondaires - pas seulement les universités, mais aussi les collèges, les instituts de recherche, les bibliothèques, les dépôts d'archives, etc. sont des éléments de la trame intellectuelle et culturelle de toute société. À terme, la vigueur d'une société dépend davantage de ces institutions que du tout pouvoir économique, industriel ou militaire.

Extrait du rapport du Groupe de travail parlementaire sur les accords fiscaux entre le gouvernement fédéral et les provinces, 1981, p. 133.

Une société éduquée est une société riche à tous égards. La société canadienne est riche, mais sa qualité, et, sans aucun doute, sa santé économique, sont menacées par la crise que traverse le secteur de l'enseignement postsecondaire.

La santé de la société canadienne, et, plus particulièrement, celle de l'économie du Canada, repose, dans une grande mesure, sur la vigueur du secteur de 
l'enseignement postsecondaire. Les secteurs privé et public ont besoin l'un et l'autre d'hommes et de femmes libéralement éduqués et à la fine pointe de leur discipline. En outre, l'industrie et le gouvernement ont besoin des recherches qu'effectuent les universités et les établissements d'enseignement postsecondaire. À une époque où l'une des seules constantes est le changement, les entreprises, les secteurs, les pays qui croissent et qui prospèrent sont ceux qui mettent 1 'accent sur la recherche et le développement et dont les employés éventuels sont éduqués et prêts à faire face aux mutations rapides du marché.

Et pourtant, le secteur de l'enseignement postsecondaire au Canada est en crise. Selon A. Johnson:

"Les finances des universités et des collèges du Canada sont dans un état précaire et incertain."

Entretemps, les gouvernements fédéral et provinciaux ne s'entendent pas sur la façon de financer l'enseignement postsecondaire. Les priorités concernant l'enseignement supérieur suscitent un profond malaise. On a porté trop peu d'attention, par exemple, au financement de la recherche par opposition aux activités de base. Ces problèmes ne font que s'ajouter aux anciennes difficultés toujours irrésolues, nées du trop grand nombre d'étudiants par rapport au corps enseignant, du manque de mobilité des étudiants, des besoins en main-d'oeuvre et de la valorisation du civisme et de l'identité linguistique et culturelle. Le fait est que dans ce siècle où foisonnent les satellites, les lasers, les ordinateurs, les missiles balistiques intercontinentaux et les transistors, dans ce siècle où le monde s'achemine si rapidement vers une "économie d'information" le Canada, chef de file dans de si nombreux domaines, ne possède pas de stratégie nationale en matière d'enseignement.

Dans son rapport général intitulé, Review of Educational Policy of Canada, publié en 1976, l'Organisation pour la coopération et le développement économique (OCDE) a tiré les conclusions suivantes en ce qui concerne l'élaboration des politiques d'enseignement au Canada. Elle a noté:

L'absence saisissante de politiques d'enseignement pour l'avenir;

Le besoin de définir des objectifs en matière d'enseignement qui correspondent à une vision de l'intérêt national;

L'existence de toute une gamme de programmes mis en oeuvre de façon exceptionnellement soutenue, mais qui ne découlent d'aucune conception nationale d'ensemble explicitement définie de l'intérêt du pays;

La nécessité de prendre aujourd'hui des décisions à l'égard de l'orientation du système scolaire canadien qui soient conformes à une conception bien pensée de la nation canadienne;

Le fait que l'absence d'un ministère fédéral de l'Éducation a créé un certain vide;

Le fait que les hommes et les femmes politiques, les partis et les gouvernements ne pourront pas éviter beaucoup plus longtemps de prendre certaines positions politiques à l'échelle du pays et non seulement à l'échelle des provinces. Ils doivent donner aux Canadiens des réponses aux problèmes du pays. Si l'État n'assume pas son rôle de chef de file et ses responsabilités - 
après tout la Constitution ne l'interdit pas - l'évolution' du système d'éducation au Canada risque d'être compromise.

Devant ces déclarations, il est très décevant que le groupe de travail Nielsen ou tout autre organisme du gouvernement ne se soit pas attaqué plus sérieusement ou décisivement aux questions de l'enseignement et de la recherche. Comme l'a signalé l'Association des universités et collèges du Canada (AUCC), le groupe de travail Nielsen "a fait fausse route en n'essayant pas de justifier le maintien de l'aide financière fédérale à l'enseignement postsecondaire”. Au lieu de formuler une recommandation précise sur le financement fédéral des établissements postsecondaires, le groupe de travail a énuméré un certain nombre d'options politiques. Au nom de l'AUCC, M. D.L. Johnston a reproché au groupe de travail d'avoir "éludé la question des priorités nationales" en ne formulant pas de recommandations précises réaffirmant le rôle du gouvernement fédéral à l'appui de l'enseignement postsecondaire.

Au moment où notre monde, devenu un village global, nous conduit vers une plus grande interdépendance, nous sommes sur le point de nous lancer dans un important débat national sur le libre-échange. Nous avons à maintes reprises essayé de mettre au point une stratégie industrielle. Nous avons traversé une récession qui nous a ébranlés et endurcis. Nous savons que la concurrence mondiale sera plus féroce que jamais. Nous savons qu'il faut nous réorganiser, trouver de nouvelles sources de financement, de nouveaux outils et procéder à notre propre réévaluation. Pourtant, bien que l'enseignement et l'ensemble du système d'éducation soient fondamentaux et essentiels, il n'y a aucun débat national, aucune tribune nationale ni aucune stratégie nationale qui mettent l'accent sur l'enseignement au Canada.

Aucun autre État fédéral du monde n'est dans cette position et aucun État moderne qui se respecte ne devrait y être. Nous prétendons avoir une stratégie financière nationale, une stratégie commerciale nationale, une stratégie en matière de défense, de transport, d'immigration, mais il n'existe aucune stratégie nationale en matière d'enseignement. Bien sûr, chaque province en possède une, mais une stratégie globale ne se limite sans doute pas à la somme de ses parties. L'ingérence croissante du gouvernement du Canada dans le domaine de l'enseignement supérieur ne peut passer inaperçue.

Plus de 50 p. 100 du financement de l'enseignement supérieur provient de crédits accordés par le Parlement du Canada. Or, on persiste à croire que l'enseignement postsecondaire relève uniquement des provinces, alors que la participation du gouvernement fédéral se fait largement et de plus en plus sentir dans de nombreux secteurs de l'enseignement supérieur: financement de base, financement de la recherche, programmes d'éducation et de formation professionnelles, une multitude de bourses d'étude et de programmes d'aide financière aux étudiants, études sur le Nord et sur les autochtones, océanographie, études canadiennes, multiculturalisme, bilinguisme, relations internationales, études militaires et dans d'autres domaines, sans oublier qu'il assume toutes ces responsabilités dans l'intérêt supérieur de la nation. 
Le gouvernement fédéral a des intérêts légitimes et indéniables dans le domaine de 1 'enseignement supérieur. Il a pour rôle de s'assurer que le pays dispose d'un nombre suffisant de personnes hautement qualifiées, que les jeunes Canadiens, où qu'ils vivent, aient accès à l'enseignement supérieur et qu'ils acquièrent les connaissances propres à assumer notre croissance économique et notre souveraineté nationale.

Il importe spécialement d'examiner la relation entre l'enseignement et les arts au Canada et de souligner la responsabilité et le rôle du gouvernement du Canada à ce sujet. M. Mavor Moore a récemment mis en relief la question dans un article du Globe and Mail.

Il a soulevé des points clés et pertinents à l'égard de nos écoles nationales d'art comme l'École nationale de théâtre à Montréal, l'École nationale de ballet à Toronto, l'École du ballet royal de Winnipeg, la Banff Centre School of Fine Arts et la Vancouver Playhouse School. Il critique sévèrement l'apathie dont nous faisons preuve envers le financement des établissements artistiques au Canada. Il signale, entre autres, que l'École nationale de thêâtre, qui forme les jeunes acteurs et les techniciens de la scène les plus prometteurs du pays, doit chaque année faire des pieds et des mains pour éviter la faillite. M. Moore indique que l'École nationale de théâtre rappelle aux Canadiens qu'ils possèdent une riche institution qui surpasse toute réalisation régionale.

"Nous semblons prêts à reconnaître la valeur de ces établissement nationaux, mais peu disposés à leur faire une place dans notre structure politique. Même le fait que l'Ecole nationale de théâtre soit reconnue à l'étranger comme l'une des meilleures du genre au monde, ne suffit pas, semble-t-il, à persuader les Canadiens qu'elle mérite un statut officiel et un appui soutenu.

Nous adoptons apparemment la même attitude à l'égard d'un grand nombre de nos établissements dits nationaux. Nous voulons à la fois avoir le drap et l'argent, c'est-à-dire à la fois les avantages d'une nation et ceux du régionalisme. Nous voulons avoir et le drap et l'argent sans au départ travailler pour les obtenir."

Nul doute qu'aujourd'hui plus que jamais dans ce monde étroit et interdépendant où la concurrence entre les entreprises est plus féroce et où les valeurs et les croyances sont constamment mises en question, il faille, à l'orée d'une nouvelle ère, celle de l'information, accroître la coordination dans le domaine de l'éducation au Canada. La Fédération canadienne des sciences sociales a souligné ce point lorsqu'elle a répondu en 1982 aux conclusions du rapport du Groupe de travail parlementaire sur les accords fiscaux qui recommandait que le conseil des ministres de l'éducation serve de tribune de consultation fédérale-provinciale. Pour la Fédération, cette façon de procéder serait inefficace. Elle proposait plutôt la création d'un conseil, le Conseil canadien de la recherche et des universités.

“...le principal mandat du Conseil serait d'énoncer, après discussion, les objectifs que devraient légitimement poursuivre les gouvernements fédéral et provinciaux en matière d'enseignement supérieur et de recherche, et de les conseiller sur l'orientation et le contenu des politiques fédérales dans ce domaine et sur leur lien avec celles des gouvernements provinciaux. En outre, le Conseil aiderait le gouvernement fédéral à énoncer plus clairement et 
efficacement l'intérêt qu'il porte à l'enseignement supérieur et à la recherche. Cet intérêt est partagé à l'heure actuelle entre différents ministères et enveloppes et semble mal défini et coordonné."

En 1984, 1'AUCC a formulé des recommandations semblables dans le troisième volume du rapport de la Commission sur les études canadiennes. L'Association a fait une analyse approfondie de la "folle mosaïque" que forme la politique canadienne en matière d'enseignement postsecondaire. Elle souligne la nécessité d'établir une stratégie nationale pour l'enseignement supérieur et la recherche avec la collaboration appropriée des universités, des collèges et des gouvernements fédéral et provinciaux.

Les auteurs du rapport proposent la formation d'un comité consultatif sur l'enseignement postsecondaire.

"En faisant cette proposition, la Commission n'ignore toutefois pas l'existence d'une variété d'organismes inter-provinciaux, fédéraux-provinciaux, ou universitaires déjà engagés sur cette voie. Il y a, par exemple, le Conseil des ministres de l'éducation du Canada, ainsi que des fragments d'appareil consultatif fédéral-provincial; et il y a des associations volontaires nationalès telles que l'Association des universités et collèges du Canada et l'Association des collèges communautaires du Canada. Mais, il faut bien l'avouer, ces organismes sont encore très loin d'avoir développé les procédés et les mécanismes qui pourraient répondre aux besoins de consultation et de collaboration sérieuses et continues dans le domaine de l'enseignement supérieur dans notre pays."

M. Thomas Symons a également demandé la formation d'un organisme semblable dans son document intitulé Ontario Universities in a Broader Context, présenté à la conférence sur les universités ontariennes, Access, Operations and Funding, organisée par le Conseil économique de l'Ontario. Il a signalé la nécessité pour le Canada de se doter de stratégies nationales en matière d'enseignement supérieur "qui pourraient être le fruit de consultations et de coopération plus poussées et soutenues entre les universités, le monde de l'éducation, entre une province et l'autre et entre les provinces, les universités et le gouvernement fédéral".

M. Symons recommande entre autres l'établissement d'un comité consultatif ou d'un conseil de l'enseignement postsecondaire et de la recherche en tant que tribune permanente regroupant des représentants des gouvernements fédéral et provinciaux et des établissements postsecondaires. Cet organisme se réunirait à intervalles réguliers pour étudier les plans et les programmes qui peuvent répondre aux besoins grandissants des Canadiens dans les domaines de l'enseignement supérieur et de la recherche.

Il me semble que pour pouvoir améliorer l'enseignement postsecondaire nous devons tout d'abord disposer d'un véhicule. Et pourquoi pas? "Nous avons, après tout, des conseils consultatifs nationaux de la Santé, du Bien-être social, de l'Économie, de la Condition de la femme, des Mines, de la Petite entreprise et d'autres encore. L'enseignement est-il donc moins important pour la nation? Un conseil consultatif national de l'enseignement ne coûterait pas très cher, mais pourrait accroître incroyablement l'excellence dans l'éducation. 
D'autres États fédéraux ont trouvé utile et nécessaire d'établir un organisme de ce type. L'Allemagne et la Suisse, par exemple, ont toutes deux jugé bon de créer, en plus des établissements administratifs et décisionnaires au palier national et à celui des États, des organismes communs comptant des représentants des deux ordres de gouvernement. En Allemagne, les deux principaux organismes de planification et de consultation, à savoir: la Commission des Bund-Landers pour la planification de l'enseignement et la promotion de la recherche et le Conseil des sciences, comptent le même nombre de membres du Bund et des Landers.

J'ai déposé il y a quelque temps, à la Chambre des communes, un projet de loi d'initiative parlementaire. Cette mesure législative, le projet de loi C-244, propose la création d'un conseil de l'enseignement postsecondaire dont la majorité des membres seraient nommés par les provinces, et les autres, par le gouvernement du Canada qui les choisirait dans le secteur de l'enseignement postsecondaire. Les modalités d'établissement de ce conseil sont bien sûr à discuter. Il faudrait de toute évidence trouver un juste équilibre entre la compétence légale des provinces et l'engagement diffus et grandissant du gouvernement national. Ce conseil serait subventionné conjointement par les gouvernements fédéral et provinciaux et son mandat consisterait à "offrir un forum de discussion du développement de l'enseignement postsecondaire au Canada et des questions d'enseignement interprovincial, national et international". Il aurait entre autres pour tâche de proposer une stratégie nationale en matière d'éducation dans les trois ans suivant sa formation.

La Fédération canadienne des enseignants va encore plus loin. Elle préconise, dans le mémoire qu'elle a présenté à la Commission royale Macdonald, la création d'un bureau canadien de l'enseignement financé conjointement par le gouvernement du Canada et les provinces et territoires. Ce bureau serait chargé de disséminer l'information à l'échelle nationale et de promouvoir la recherche en éducation. Il étudierait les problèmes d'ordre fiscal et recommanderait des solutions. En outre, il coordonnerait les activités fédérales dans le domaine de l'enseignement en favorisant l'adoption de politiques communes sur l'enseignement au Canada.

Ce bureau serait subventionné par un conseil canadien de l'enseignement qui prendrait avis et conseils auprès de tout l'éventail des secteurs d'activités au Canada.

J'appuie les propositions de la FCE qui constituent des objectifs auxquels nous devrions aspirer et vers quoi il faudrait tendre. Ils seraient toutefois plus difficiles à atteindre à court terme que celui de la coordination de l'enseignement postsecondaire. S'il y a un commencement à tout, je crois qu'il faudrait logiquement commencer par instituer un Conseil canadien de l'enseignement postsecondaire. C'est un objectif que nous pouvons et que nous devons atteindre.

À mon avis, une stratégie nationale en matière d'enseignement s'impose aujourd'hui de toute urgence au Canada. Mais nous devrions d'abord mettre de l'ordre dans le fatras qui caractérise l'enseignement au Canada pour arriver à établir cette stratégie. Une meilleure coordination de l'enseignement postsecon- 
daire et, plus tard, de tout le secteur de 1'enseignement se fait attendre depuis longtemps.

Nous disposons d'énormes ressources au Canada, mais les plus importantes sont nos ressources humaines et, plus particulièrement, notre jeunesse. Or, un récent rapport du Comité sénatorial sur la jeunesse nous indique que celle-ci est en passe de devenir "une génération perdue". Le $\mathrm{XX}^{\mathrm{e}}$ siècle appartient-il au Canada comme l'a dit Sir Wilfrid Laurier? Faisons-nous partie des cinq pays du monde dont l'influence grandit? Avons-nous atteint la maturité au niveau international, découvert qui nous sommes et vaincu notre sentiment d'infériorité devant les grandes puissances mondiales? Voyons comment notre économie se compare à celle de l'Allemagne de l'Ouest, puis comment notre système d'enseignement se compare au sien. Puis faisons les mêmes comparaisons avec le Japon. Quels sont nos objectifs et quelle est notre vision du Canada?

Il est temps de placer l'éducation au premier rang de nos priorités. Cherchons à établir une stratégie nationale en matière d'enseignement en commençant par mettre de l'ordre dans nos affaires. C'est le plus grand défi que le Canada doit relever de nos jours; s'y soustraire compromettrait l'avenir du pays. 